\title{
Aplikasi Augmented Reality Pengenalan Bangunan Adat Desa Penglipuran
}

\author{
Anak Agung Ngurah Hary Susila*, Dewa Made Sri Arsa \\ Fakultas Teknik, Program Studi Teknologi Informasi, Universitas Udayana, Bali, Indonesia \\ Email: 1,"harysusila@unud.ac.id, ${ }^{2,}$ dewamsa@unud.ac.id \\ Email Penulis Korespondensi: harysusila@unud.ac.id
}

\begin{abstract}
Abstrak-Desa Penglipuran merupakan desa wisata yang ada di Pulau Bali. Salah satu daya tarik Desa Penglipuran adalah bangunan adat yang seragam dan memiliki ciri khas yang masih dipertahankan sejak zaman dahulu. Banyak wisatawan yang berkunjung dan berfoto di depan bangunan adat, namun tidak mengetahui informasi yang jelas mengenai nama dan fungsi bangunan tersebut. Tujuan penelitian ini adalah merancang aplikasi sebagai media informasi pengenalan bangunan adat Desa Penglipuran menggunakan teknologi Augmented Reality. Model penelitian yang digunakan untuk perancangan aplikasi adalah model waterfall. Aplikasi Augmented Reality ini dibangun dengan software Autodesk Maya dan Unity sehingga dapat menampilkan informasi bangunan adat 3D ke lingkungan nyata dengan memanfaatkan media brosur sebagai marker. Hasil penelitian adalah berhasil merancang aplikasi Augmented Reality yang dapat memberikan informasi mengenai bangunan adat Desa Penglipuran dalam bentuk animasi 3D, narasi teks dan audio.
\end{abstract}

Kata Kunci: Aumented Reality, Desa Penglipuran, Bangunan Adat, Brosur, Marker

\begin{abstract}
Penglipuran Village is a tourism village on the island of Bali. One of the attractions of Penglipuran Village is the traditional, uniform building that has characteristics that are still maintained since ancient times. Many tourists who visit and take pictures in front of a traditional building, but do not know clear information about the name and function of the building. The purpose of this study is to design an application as an information medium for the introduction of traditional buildings in Penglipuran Village using Augmented Reality technology. The research model used for application design is the waterfall model. This Augmented Reality application was built with Autodesk Maya and Unity software so that it can display 3D custom building information to the real environment by using the brochure media as a marker. The results of the study were successful in designing an Augmented Reality application that can provide information about the traditional buildings of Penglipuran Village in the form of 3D animation, text and audio narration.
\end{abstract}

Keywords: Augmented Reality, Penglipuran Village, Traditional Building, Brochure, Marker

\section{PENDAHULUAN}

Masyarakat saat ini tidak dapat dilepaskan dari penerapan teknologi dalam kehidupan sehari-hari seperti bekerja, belajar, liburan dan lain sebagainya. Salah satu teknologi yang berkembang saat ini adalah teknologi Augmented Reality. Teknologi ini dapat menggabungkan benda maya 2D ke lingkungan nyata 3D dan menampilkan benda maya tersebut kedalam waktu nyata [1]. Augmented Reality banyak dimanfaatkan sebagai media informasi pembelajaran atau pengenalan suatu objek wisata yang dapat diberikan kepada penggunanya.

Desa Penglipuran merupakan desa wisata yang terkenal dan dinobatkan menjadi salah satu Desa terbersih di dunia. Selain predikat Desa terbersih, Desa Penglipuran juga memiliki daya tarik wisata yang berbeda dari desa-desa wisata di Pulau Bali. Daya tarik tersebut adalah bangunan rumah adatnya yang memiliki ciri dan khas yang masih dipertahankan dari zaman dahulu. Terdapat 76 kavling rumah yang terbagi menjadi dua sisi yaitu sisi Barat berjumlah 38 dan sisi Timur berjumlah 38. Setiap rumah memiliki bangunan yang seragam dan masih mempertahankan bentuk serta bahan material berupa tanah liat, batu bata dan bambu. Bangunan adat ini terdiri dari Gapura atau yang disebut Angkul-angkul merupakan pintu masuk pekarangan rumah, balai Sakanem yaitu bangunan untuk melaksanakan upacara agama seperti potong gigi dan kematian, balai Paon yaitu bangunan yang berfungsi sebagai tempat memasak dan tempat tidur keluarga [2].

Keunikan bangunan adat ini menjadi daya tarik wisatawan domestik maupun mancanegara yang berkunjung ke Desa Penglipuran. Banyak wisatawan yang berkunjung untuk melihat keunikan Desa Penglipuran maupun hanya ingin sekedar berfoto di depan bangunan adatnya, namun banyak dari wisatawan tersebut yang juga tidak mengetahui informasi mengenai nama, fungsi dan tata letak bangunan adat tersebut. Selain itu, beberapa wisatawan yang berkunjung juga tidak menggunakan jasa guide yang mampu memberikan informasi yang jelas mengenai bangunan adat di Desa ini.

Berdasarkan permasalahan tersebut maka diperlukan sebuah media informasi berbasis teknologi yang mampu memberikan serta menjelaskan informasi bangunan adat Desa Penglipuran kepada wisatawan domestik maupun mancanegara. Tujuan penelitian ini adalah merancang aplikasi media informasi menggunakan teknologi Augmented Reality sebagai pengenalan bangunan adat Desa Penglipuran. Media brosur digunakan sebagai untuk marker dan akan menghasilkan objek 3D bangunan adat Desa penglipuran, serta informasi yang dilengkapi dengan narasi teks dan audio.

Penelitian ini menggunakan beberapa jurnal sebagai referensi dan pembanding. Penelitian yang berjudul Pengenalan Rumah Adat Indonesia Berbasis Augmented Reality dengan Memanfaatkan KTP sebagai Marker. Penelitian ini dirancang untuk mempermudah masyarakat dalam mengenal rumah adat dalam bentuk 3D, informasi umum tentang rumah adat dan gambar rumah adat dengan menggunakan kartu KTP sebagai marker 
JURNAL MEDIA INFORMATIKA BUDIDARMA

Volume 4, Nomor 3, Juli 2020, Page 726-734

ISSN 2614-5278 (media cetak), ISSN 2548-8368 (media online)

Available Online at https://ejurnal.stmik-budidarma.ac.id/index.php/mib

DOI 10.30865/mib.v4i3.2208

untuk mengakses aplikasi [3]. Penelitian selanjutnya yang berjudul Augmented Reality Book Pengenalan Tata Letak Bangunan Pura Pulaki dan Pura Melanting. Tujuan penelitian ini adalah untuk memberikan informasi mengenai tata letak bangunan Pura dengan memanfaatkan teknologi Augmented Reality Book berbasis Android. Hasil penelitian berupa buku yang dijadikan marker dan aplikasi Augmented Reality yang menampilkan objek bangunan Pura Pulaki dan Melanting dalam bentuk 3D [1]. Penelitian selanjutnya yang menggunakan teknologi Augmented Reality pengenalan lokasi Wisata Kota Semarang dengan menggunakan teknologi Augmented Reality. Tujuan penelitian ini adalah membuat aplikasi yang dapat memberikan informasi objek wisata yang lebih menarik dan informatif dalam bentuk 3D, audio dan menunjukkan letak lokasi wisata [4]. Penelitian tentang Learning Media of Balinese Script Writing based on Augmented Reality bertujuuan untuk membuat media pembelajaran dan pengenalan penulisan aksara Bali. Aplikasi ini berbasis Android dan menghasilkan animasi 3 dimensi tulisan dan suara penulisan Aksara Bali serta penjelasan penggunaan Aksara Bali dan contoh kata pada setiap Aksara Bali [5]. Penelitian Augmented Reality tentang pengenalan tempat wisata Museum Bali dan Pura Tanah Lot Bali. Hasil dari masing-masing penelitian ini adalah aplikasi yang dapat memunculkan objek 3D, informasi berupa video dan audio [6], [7]. Berdasarkan penelitian yang terdahulu, penelitian ini akan menggunakan teknologi Augmented Reality berbasis Android sebagai media informasi pengenalan bangunan adat di Desa Penglipuran yang dapat memberikan informasi objek 3D, narasi teks dan audio melalui media brosur.

\section{METODOLOGI PENELITIAN}

\subsection{Kerangka Penelitian}

Kerangka penelitian yang digunakan untuk menyelesaikan masalah yaitu model pengembangan perangkat lunak waterfall. Model waterfall digunakan karena model ini menyediakan proses secara sekuensial linier atau berurutan yang dimulai dari analisis data, perancangan sistem, implementasi, pengujian dan evaluasi [8]. Kerangka penelitian dapat dilihat pada Gambar 1.

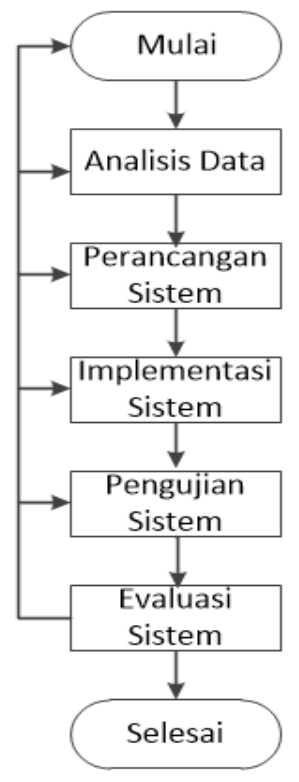

Gambar 1. Kerangka Penelitian

Berikut penjelasan mengenai kerangka penelitian pada Gambar 1 sebagai berikut:

a. Analisis Data

Tahap awal analisis data dilakukan dengan cara wawancara, observasi dan pengamatan secara langsung mengenai permasalahan dan data bangunan adat Desa Penglipuran.

b. Perancangan Sistem

Tahap perancangan sistem adalah proses perancangan desain aplikasi seperti desain interface, pembuatan marker dan desain brosur.

c. Implementasi Sistem

Tahap ini akan dilaksanakan implementasi aplikasi yang ada pada tahap perancangan sistem untuk menjadi aplikasi menggunakan Unity3d.

d. Pengujian Sistem

Tahap pengujian aplikasi menggunakan metode Black Box. Metode Black Box yaitu menguji fungsionalitas input atau output dari sebuah aplikasi/ perangkat lunak [9]. Pengujian akan dilakukan pada seluruh menu 
JURNAL MEDIA INFORMATIKA BUDIDARMA

Volume 4, Nomor 3, Juli 2020, Page 726-734

ISSN 2614-5278 (media cetak), ISSN 2548-8368 (media online)

Available Online at https://ejurnal.stmik-budidarma.ac.id/index.php/mib

DOI 10.30865/mib.v4i3.2208

yang terdapat pada aplikasi dan tingkat kecepatan aplikasi pada smartphone. Pengujian aplikasi tidak melihat bagaimana proses untuk menghasilkan keluaran

e. Evaluasi Sistem

Tahap terakhir dari penelitian ini adalah evaluasi aplikasi. Evaluasi ini dilakukan setelah melakukan tahapan pengujian aplikasi. Jika pada tahapan pengujian terjadi permasalahan atau tidak sesuai dengan perancangan aplikasi, maka akan dilakukan proses ke tahapan sebelumnya untuk memperbaiki permasalahan tersebut.

\subsection{Gambaran Umum Aplikasi}

Gambaran umum aplikasi Augmented Reality bangunan adat Desa Penglipuran dapat dilihat pada Gambar 2.

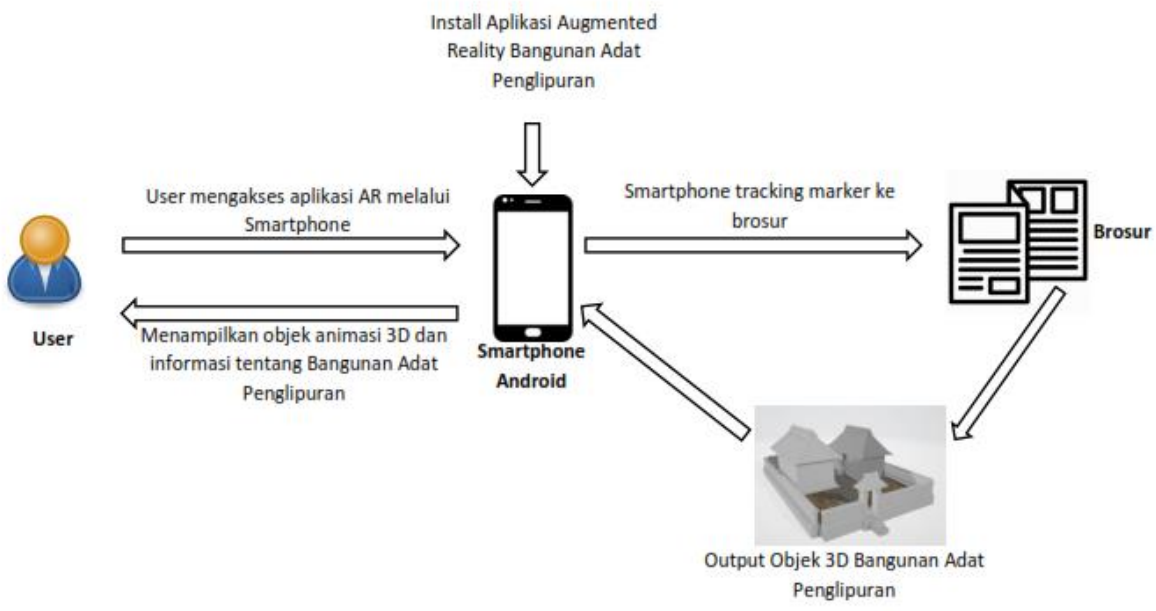

Gambar 2. Gambaran Umum Aplikasi

Gambar 2 merupakan gambaran umum sistem aplikasi Augmented Reality bangunan adat Desa Penglipuran. Terdapat beberapa proses yaitu user harus mengakses Aplikasi ini melalui smartphone yang telah di-install aplikasi Augmented Reality. Setelah itu smartphone akan tracking image menggunakan kamera pada brosur untuk menemukan data marker yang telah dibuat sebelumnya. Hasil tracking tersebut akan didapatkan objek 3D bangunan adat Desa Penglipuran dan smartphone menampilkan informasi berupa objek animasi 3D, narasi teks dan audio kepada user.

\subsection{Bangunan Adat Desa Penglipuran}

Desa Penglipuran memiliki 76 kavling rumah yang dibagi menjadi dua daerah yaitu sisi Barat dan sisi Timur. Masing-masing sisi memiliki 38 kavling rumah dan memiliki luas yang sama. Setiap satu unit rumah warga terdapat 1 angkul-angkul (pintu masuk utama), bangunan Merajan, bangunan Sakanem,bangunan Loji dan Paon (Dapur) [10]. Gambar 3 merupakan bangunan adat Desa Penglipuran.

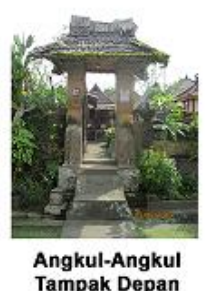

Angkul-Angkut
Tampak Depan

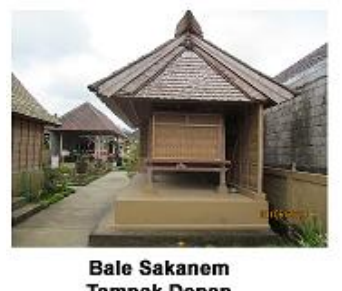

Tampak Depan
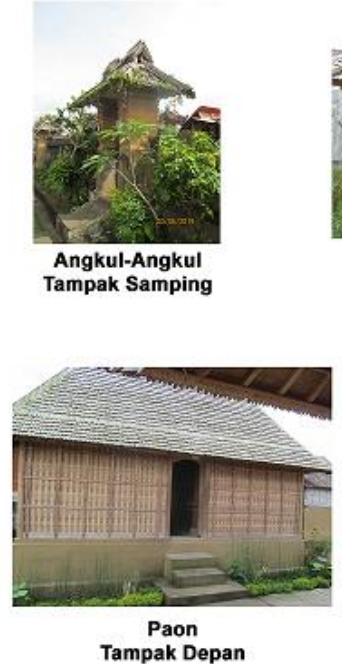
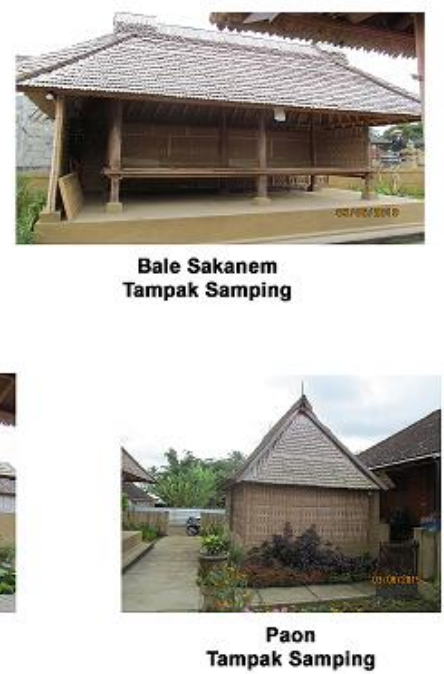

Gambar 3. Bangunan Adat Desa Penglipuran 
JURNAL MEDIA INFORMATIKA BUDIDARMA

Volume 4, Nomor 3, Juli 2020, Page 726-734

ISSN 2614-5278 (media cetak), ISSN 2548-8368 (media online)

Available Online at https://ejurnal.stmik-budidarma.ac.id/index.php/mib DOI 10.30865/mib.v4i3.2208

\subsection{Augmented Reality}

Augmented Reality adalah penggabungan benda atau objek dunia maya ke dunia nyata dan dapat berinteraksi pada waktu yang nyata dalam bentuk 3D [11]. Dua metode untuk membuat marker pada Augmented Reality yaitu Markerless Based Tracking dan Marker Based Tracking [12]. Pada penelitian ini menggunakan Marker Based Tracking dengan bantuan menggunakan media brosur.

\section{HASIL DAN PEMBAHASAN}

\subsection{Rancangan UML}

\section{a. Use Case Diagram}

Use case diagram digunakan untuk menggambarkan hubungan antara user dengan hal-hal yang dapat dilakukan pada aplikasi [13]. Berikut use case diagram dapat dilihat pada Gambar 4.

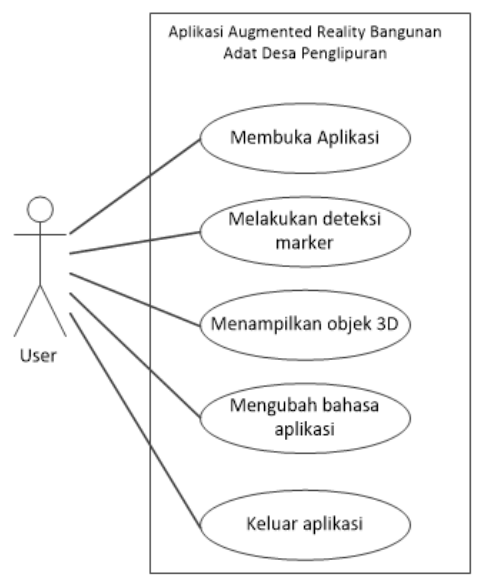

Gambar 4. Use Case Diagram Aplikasi

Gambar 4 terdapat actor atau user yang dapat menggunakan aplikasi untuk mendeteksi marker, menampilkan objek 3D, memilih dan mengubah bahasa aplikasi dan keluar dari aplikasi.

\section{b. Activity Diagram}

Activity diagram menggambarkan aliran kerja atau aktivitas dari aplikasi Augmented Reality pengenalan bangunan adat Desa Penglipuran. Activity diagram ditentukan berdasarkan use case diagram pada Gambar 4.

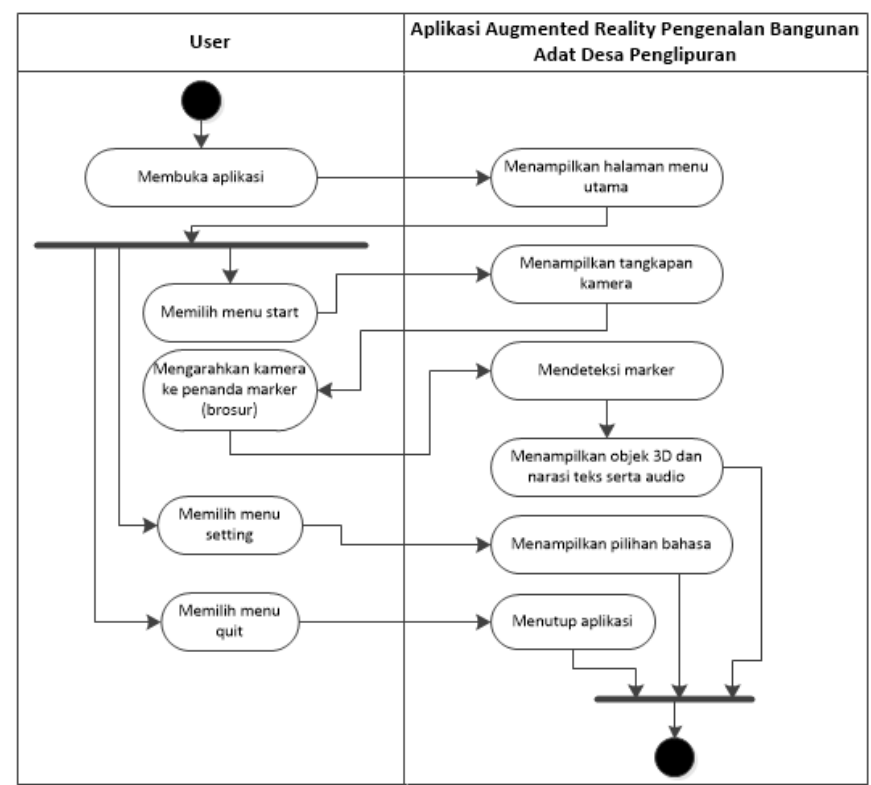

Gambar 5. Activity Diagram Aplikasi 
JURNAL MEDIA INFORMATIKA BUDIDARMA

Volume 4, Nomor 3, Juli 2020, Page 726-734

ISSN 2614-5278 (media cetak), ISSN 2548-8368 (media online)

Available Online at https://ejurnal.stmik-budidarma.ac.id/index.php/mib

DOI 10.30865/mib.v4i3.2208

Gambar 5 merupakan activity diagram dari aplikasi. Terdapat beberapa aktivitas pada aplikasi, seperti aktivitas dimulai dengan membuka aplikasi, menampilkan halaman menu utama, mendeteksi marker, menampilkan objek 3D beserta narasi teks dan audio. Aliran kerja untuk menampilkan pilihan bahasa dengan memilih menu setting lalu pilih bahasa untuk aplikasi. Aktivitas keluar dari aplikasi yaitu memilih menu quit dan aplikasi akan tertutup.

\subsection{Perancangan Animasi 3D Bangunan Adat}

Perancangan animasi 3D terdiri dari bangunan adat Gapura, Sakanem dan Paon. Pembuatan animasi 3D menggunakan software Autodesk Maya. Tabel 1 merupakan hasil perancangan animasi 3D bangunan adat.

Tabel 1. Animasi Bangunan Adat

\begin{tabular}{clll}
\hline Nama Bangunan Adat & Foto Bangunan Adat & Gambar 3D \\
\hline Gapura & & \\
Sakanem & &
\end{tabular}

Tabel 1. merupakan hasil perancangan animasi 3D bangunan adat Desa Penglipuran. Pembuatan objek animasi 3D berdasarkan foto-foto bangunan adat yang didapatkan pada saat melakukan observasi ke Desa Penglipuran. Perancangan user interface aplikasi terdiri dari tampilan halaman utama,menu start, menu setting dan quit. Gambar 6 merupakan rancangan user interface aplikasi.

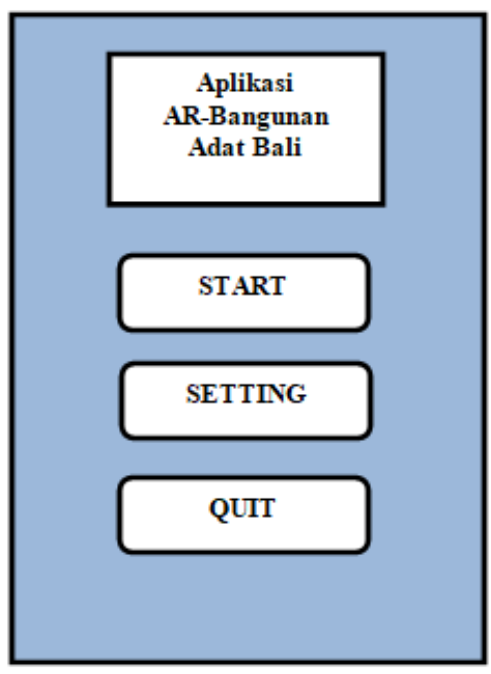

Gambar 6. Rancangan User Interface Aplikasi

Pada Gambar 6 terdapat halaman utama yang berisi tentang menu start yaitu menu yang digunakan untuk menampilkan kamera smartphone dan mendeteksi marker agar menampilkan objek 3D. Menu setting merupakan menu untuk mengubah bahasa yang akan digunakan. Bahasa yang dapat dipilih yaitu bahasa Indonesia dan Inggris. Terakhir menu quit yaitu digunakan untuk keluar dari aplikasi. 
JURNAL MEDIA INFORMATIKA BUDIDARMA

Volume 4, Nomor 3, Juli 2020, Page 726-734

ISSN 2614-5278 (media cetak), ISSN 2548-8368 (media online)

Available Online at https://ejurnal.stmik-budidarma.ac.id/index.php/mib DOI $10.30865 /$ mib.v4i3.2208

\subsection{Implementasi}

Implementasi merupakan tahapan untuk membuat aplikasi dari perancangan yang telah dikerjakan pada tahap sebelumnya. Rancangan aplikasi yang akan diimplementasikan adalah animasi 3D bangunan adat, menu utama, start, setting dan quit. Berikut hasil dari implementasi aplikasi.

a. Menu Utama

Tampilan Menu utama merupakan tampilan halaman yang muncul pada awal dibukanya aplikasi oleh user. Berikut tampilan Menu utama dapat dilihat pada Gambar 7.

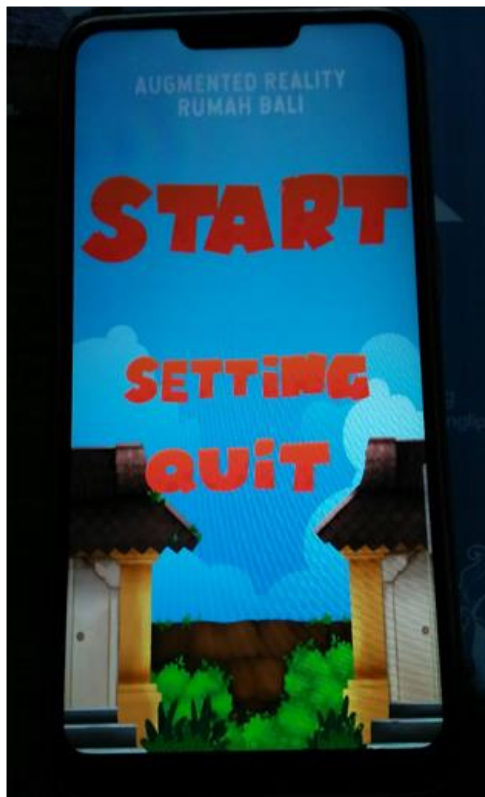

Gambar 7. Tampilan Menu Utama Aplikasi

Gambar 7 menampilkan halaman utama yang berisi menu start, setting dan quit. Untuk menggunakan aplikasi ini user dapat memilih salah satu menu tersebut. Menu start untuk menampilkan kamera smartphone, menu setting untuk memilih bahasa dan menu quit untuk keluar dari aplikasi.

\section{b. Menu Start}

Menu start adalah tampilan untuk membuka kamera smartphone yang akan digunakan untuk mendeteksi marker pada brosur. Gambar 8 merupakan tampilan menu start ketika dijalankan.

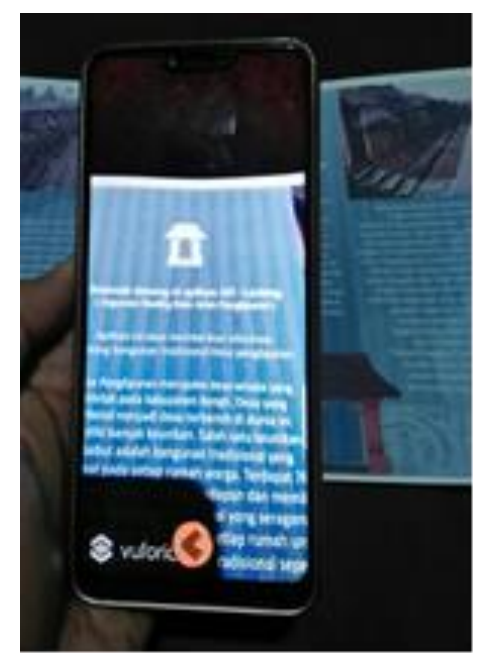

Gambar 8. Tampilan Menu Start

Gambar 8 merupakan tampilan setelah memilih menu start pada aplikasi. Tampilan ini akan membuka langsung kamera smartphone untuk membaca dan mendeteksi marker pada brosur. User perlu mengarahkan kamera smartphone ke foto-foto bangunan adat yang telah disediakan pada brosur. Setelah marker terdeteksi, maka akan menampilkan animasi 3D bangunan adat serta informasi teks dan audio tentang bangunan adat tersebut. Gambar 9 contoh tampilan animasi 3D bangunan adat yang muncul setelah marker terdeteksi. 


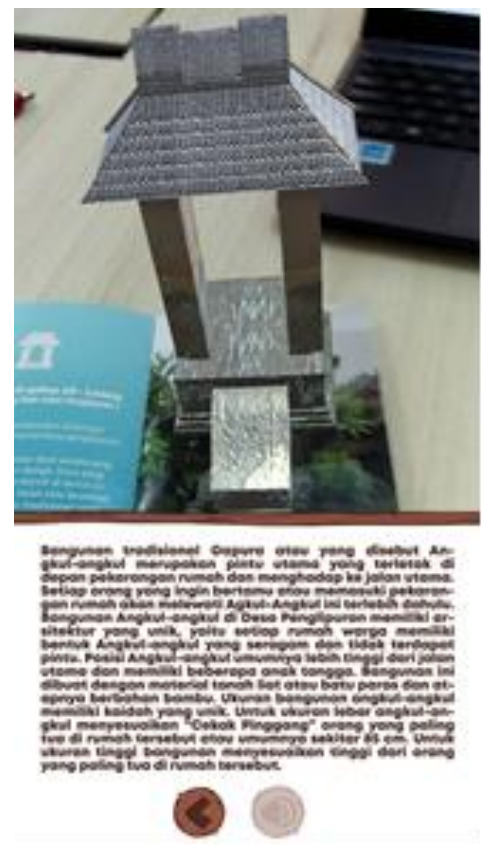

Gambar 9. Tampilan Hasil Marker Terdeteksi Pada Brosur

Gambar 9 merupakan hasil tampilan setelah kamera smartphone berhasil mendeteksi marker dan menampilkan animasi 3D. Informasi yang dapat ditampilkan pada layar smartphone antara lain animasi 3D, informasi terkait bangunan adat berupa narasi teks dan audio. User dapat memilih untuk mematikan audio dengan cara menekan tombol speaker dan dapat kembali ke menu awal dengan menekan tombol back.

\section{c. Menu Setting}

Menu setting merupakan tampilan untuk memilih bahasa yang akan digunakan pada aplikasi. Gambar 10 tampilan menu setting.

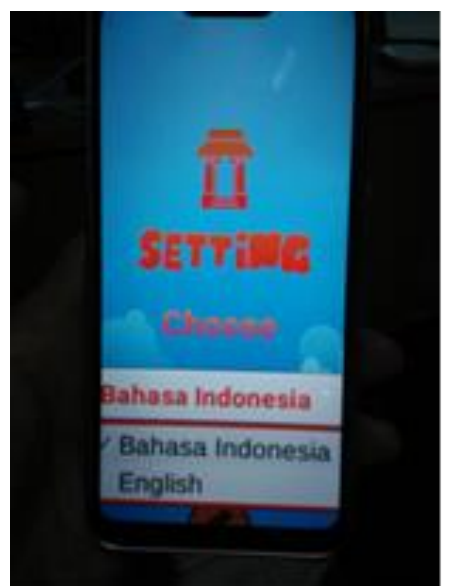

Gambar 10. Tampilan Menu Setting

Tampilan menu setting pada Gambar 10 merupakan pengaturan pemilihan bahasa yang terdapat pada aplikasi. Terdapat pilihan bahasa Indonesia dan Inggris yang dapat dipilih oleh user untuk melihat dan mendengar informasi mengenai bangunan adat Desa Penglipuran. Terdapat tombol back yang digunakan untuk kembali ke halaman utama.

\section{d. Quit}

Menu quit digunakan user jika telah selesai menggunakan aplikasi sehingga aplikasi akan keluar dan kembali pada home screen smartphone.

\subsection{Pengujian Aplikasi}

Pengujian aplikasi menggunakan metode Black Box. Pengujian aplikasi hanya dilakukan pada keluaran seluruh fungsi menu dan tingkat kecepatan aplikasi pada smartphone. Pengujian aplikasi menggunakan smartphone 
JURNAL MEDIA INFORMATIKA BUDIDARMA

Volume 4, Nomor 3, Juli 2020, Page 726-734

ISSN 2614-5278 (media cetak), ISSN 2548-8368 (media online)

Available Online at https://ejurnal.stmik-budidarma.ac.id/index.php/mib

DOI 10.30865/mib.v4i3.2208

android dengan spesifikasi processor smartphone Android Octa-core $1.8 \mathrm{GHz}$, sistem operasi Oreo, memory (RAM) 2 GB, layar 6.2 inci HD dan kamera smartphone 8 MP. Berikut Tabel 2 hasil pengujian fungsi menu yang ada pada aplikasi.

Tabel 2. Pengujian Fungsi Menu Aplikasi

\begin{tabular}{|c|c|c|}
\hline No & Pengujian Menu & Hasil \\
\hline 1 & Halaman utama & Berhasil menampilkan halaman utama \\
\hline 2 & Start & Berhasil menampilkan kamera smartphone \\
\hline 3 & Setting & Berhasil menampilkan menu pilihan bahasa \\
\hline 4 & Memilih bahasa & Berhasil memilih bahasa Indonesia atau Inggris \\
\hline 5 & Quit & $\begin{array}{l}\text { Berhasil keluar dari aplikasi dan kembali ke home screen } \\
\text { smartphone }\end{array}$ \\
\hline 6 & $\begin{array}{l}\text { Tampilan animasi 3D bangunan adat } \\
\text { Gapura }\end{array}$ & $\begin{array}{l}\text { Berhasil mendeteksi marker pada brosur dan memunculkan } \\
\text { animasi 3D Gapura }\end{array}$ \\
\hline 7 & $\begin{array}{l}\text { Tampilan animasi 3D bangunan adat } \\
\text { Sakanem }\end{array}$ & $\begin{array}{l}\text { Berhasil mendeteksi marker pada brosur dan memunculkan } \\
\text { animasi 3D Sakanem }\end{array}$ \\
\hline 8 & $\begin{array}{l}\text { Tampilan animasi 3D bangunan adat } \\
\text { Paon }\end{array}$ & $\begin{array}{l}\text { Berhasil mendeteksi marker pada brosur dan memunculkan } \\
\text { animasi 3D Paon }\end{array}$ \\
\hline
\end{tabular}

Pada Tabel 2 pengujian untuk seluruh menu pada aplikasi sudah dilakukan dengan hasil seluruh menu dapat berfungsi dan berjalan dengan baik. Pengujian berikutnya tentang kecepatan aplikasi pada smartphone dapat dilihat pada Tabel 3 berikut.

Tabel 3. Pengujian Kecepatan Aplikasi

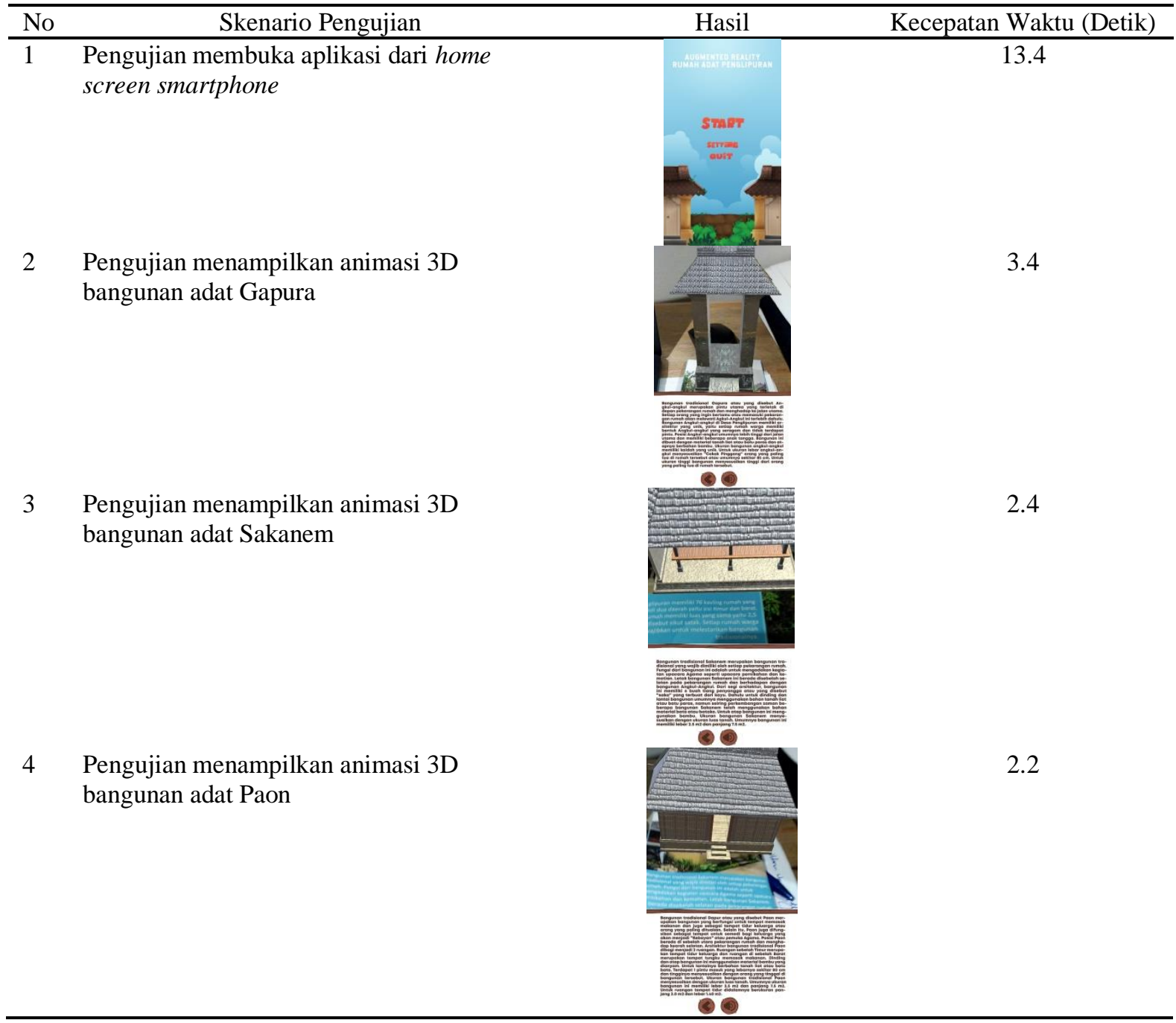



DOI 10.30865/mib.v4i3.2208

\begin{tabular}{lllc}
\hline No & Skenario Pengujian & Hasil & Kecepatan Waktu (Detik) \\
\hline 5 & Pengujian membuka menu setting & & 1.7 \\
& & & \\
& & SETritis \\
& & \\
\hline
\end{tabular}

Tabel 3 menampilkan hasil pengujian kecepatan aplikasi pada smartphone dengan 5 skenario yang telah dilakukan. Hasil dari pengujian kecepatan diketahui paling lambat saat skenario membuka aplikasi dari home screen smartphone dan paling cepat adalah saat skenario keluar dari aplikasi. Menampilkan animasi 3D pada smartphone diketahui rata-rata kecepatannya yaitu 2.7 detik.

\section{KESIMPULAN}

Simpulan yang didapat dari hasil penelitian aplikasi Augemented Reality bangunan adat Desa Penglipuran adalah berhasil merancang suatu media informasi menggunakan teknologi Augmented Reality untuk pengenalan bangunan adat Desa Penglipuran. Aplikasi ini dapat memberikan informasi berupa narasi teks dan audio beserta dapat memilih bahasa yang diinginkan untuk mengetahu informasi tersebut. Marker pada brosur dapat terdeteksi dengan baik sehingga mampu menampilkan animasi 3D, informasi narasi teks serta audio mengenai bangunan adat pada smartphone. Kecepatan aplikasi pada smartphone diketahui untuk menampilkan animasi 3D dan informasi rata-rata 2.7 detik. Kecepatan aplikasi paling cepat saat keluar dari aplikasi, sedangkan kecepatan paling lambat saat membuka aplikasi dari home screen smartphone.

\section{UCAPAN TERIMAKASIH}

Terima kasih disampaikan kepada LPPM Unud, Fakultas Teknik Program Studi Teknologi Informasi yang telah membantu terlaksananya penelitian ini.

\section{REFERENCES}

[1] P. Y. A. Prawira, P. N. Crisnapati, M.G. Sunarya, and G. M. Darmawiguna, "Augmented Reality Book Pengenalan Tata Letak Bangunan Pura Pulaki dan Pura Melanting," Jurnal Nasional Pendidikan Teknik Informatika, vol. 4, no. 2, pp. 78-86, 2015.

[2] M. M. Sudarwani, and I. Priyoga, "Kajian Pola Ruang dan Rumah Tradisional Desa Penglipuran”, Jurnal Ilmiah Arsitektur dan Lingkungan Binaan," vol. 16, no. 2, pp. 248-257, 2018

[3] R. Prabowo, T. Listyorini, and A. Jazuli, "Pengenalan Rumah Adat Indonesia Berbasis Augmented Reality dengan Memanfaatkan KTP Sebagai Marker," Prosiding SNATIF 2, pp. 51-58, 2015.

[4] R. Wiratama, M. Somantri, and Y. Christyono, "Rancang Bangun Pengenalan Lokasi Wisata Kota Semarang dengan Menerapkan Teknologi Reality Tertambah Menggunakan Unity dan Vuforia,” Transient, vol. 7, no. 1, pp. 186-192, 2018.

[5] A. A. K. O. Sudana, K. S. Wibawa, and I. M. A. D. Tirtha, "Learning Media of Balinese Script Writing based on Augmented Reality," Journal of Theoretical and Applied Information Technology, vol. 90, no.1, 2016.

[6] A. Nugraha, D. Putra, and Sukarsa, "Rancang Bangun Aplikasi Android AR Museum Bali: Gedung Karangasem dan Gedung Tabanan," Jurnal Lontar Komputer, vol. 7, no. 2, pp. 93-103, 2016.

[7] A. F. Waruwu, A. Bayupati, and D. Putra, "Augmented Reality Mobile Application of Balinese Hindu Temples: DewataAR,” I. J. Computer Network and Information Security, pp. 59-66, 2015

[8] Apriyanto, and F. A. Salwa, "Penerapan Model Waterfall Dalam Pembuatan Aplikasi Toko Kado," IJCIT (Indonesian Journal on Computer and Information Technology), Vol. 3, No. 2, pp. 234-242, 2018.

[9] T. Wahyunningrum, and D. Januarita, "Implementasi dan Pengujian Web E-Commerce untuk Produk Unggulan Desa," Jurnal Komputer Terapan, Vol. 1, No. 1, pp. 57-66, 2015.

[10] P. Kasuma, and I. Suprijanto, "Karakteristik Ruang Tradisional pada Desa Adat Penglipuran, Bali," Jurnal Permukiman, vol. 7, no. 1, pp. 40-50. 2012.

[11] Sugianto, "Implementasi Augmented Reality pada Brosur Rental Mobil CV. Asmoro Jati Menggunakan Metode Marker," Skripsi. Semarang: Universitas Dian Nuswantoro. 2014.

[12] M. Z. Devita, S. Andryana, and D. Hidayatullah, "Augmented Reality Pengenalan Huruf dan Angka Arab Menggunakan Metode Marker Based Tracking Berbasis Andorid", Jurnal Media Informatika Budidarma, Vol. 4, no. 1, pp. 14-21, 2020.

[13] K. Fathoni, Y. Setiowati, and R. Muhammad, "Rancang Bangun Aplikasi Modul Pembelajaran Satwa Untuk Anak Berbasis Mobile Augmented Reality”, Jurnal Media Informatika Budidarma, Vol. 4, no. 1, pp. 32-41, 2020. 